\title{
Characteristics of education in entrepreneurial economy
}

\author{
D Săvescu ${ }^{1}$ \\ ${ }^{1}$ Product Design, Mechatronics and Environment Department, Transilvania University of \\ Braşov, Romania \\ E-mail: dsavescu@unitbv.ro
}

\begin{abstract}
Paper presents some aspects regarding entrepreneurial economy, short history concerning the fathers of entrepreneur concept, classic and neoclassic theories, the importance of education in entrepreneurial economy, and percent of GDP dedicated to education and innovative research; a short comparison between some economies (US, Germany, Sweden, Japan, a.s.o.), and Romania.
\end{abstract}

Keywords: economy, entrepreneur, education, innovative research

\section{Introduction}

The overwhelming majority of products (and services) now reach the consumer through the market, and any commodity and service exchange is mediated through money. Generally a market economy is a capitalist one, in which capital accumulation and investment in profitable activities play the central role. "... The so-called progress towards capitalism is, from The Middle Ages, the univocal criterion of modernizing the economy "(Max Weber).

Market operates according to the requirements of economic effectiveness under the law of supply and demand: any activity is justified on the market by its economic effectiveness that is by its profitability; an ineffective, unprofitable activity is eliminated from the market, better it is eliminated alone, unable to resist to competition.

The market economy can only be a free one in which economic agents can take by themselves the decisions most appropriate to their own interest, which they know best; interest which corresponds to the economic efficiency and, implicitly, the realization of the profit. The wrong decisions of owners are economically sanctioned - bankruptcy. On the other hand, the market economy also includes freedom of labour - based on the abolition of any personal dependence of one person to another - her right to engage or not in the conditions of a contract negotiated, for any kind of activity. The idea and the implementation of the contract are essential for a market economy, assuming equality before the law of the contracting parties as well as the equal obligation of all parties to comply with the terms of a contract freely assumed.

\section{The concept of entrepreneurial economy}

Entrepreneurial economy appears as a two-dimensional concept [1]:

- Static size - refers to business ownership at national level (Macro);

- The dynamic dimension - refers to the entrepreneurial behaviour in general. 
Entrepreneurship contributes to the economic growth of any country. Internationally, entrepreneurship differs according to the levels of development economic and institutional structures of each country.

Over time, there have been many forms of entrepreneurship due to trends and development of existing technologies. In many countries, tax legislation, public sector development and tightening conditions market entry have boosted the decline of the small business sector.

\section{Classic and neoclassic entrepreneurial theories}

Entrepreneurial theories have existed for many years. They have contributed to the development and the formation of entrepreneurship as a science. Among the classical thinkers who have formulated the theories about entrepreneurship, the most known were R. Cantillon and J. B. Say [2].

Richard Cantillon (1680-1734) was the first economist who used the term of entrepreneur. His most important contribution was to recognize that the function of entrepreneurship exists in the economic system at both micro and macro level (i.e. within the business and economy).

Cantillon has identified three different forms of entrepreneurship:

- landowners, whom he called capitalists;

- entrepreneurs, whom they called referees;

- paid managers.

In a sense, the entrepreneur creates a balance between supply and demand. In conclusion, Cantillon's entrepreneur was, first and foremost, a speculator. He invite always to be alert and have relationships, look ahead and be willing to assume one risk, but not necessarily an innovative one. After Cantillon, the products and processes of a particular branch of activity were fixed and that's why improvement or innovation has not big importance.

Jean-Baptiste Say (1767-1832) believes that the entrepreneur has a central role both in the production and distribution of goods and services produced and consumed by society overall. He was the first economist who presented the difference between entrepreneur and manager. Unlike other economists, Say gives entrepreneurship a special position, important in the production and consumption system. Say removes attention from the role of entrepreneur, treating his work as a superior form. Say's entrepreneurs dedicate their time, talent, and resources to producing, distribution and consumption of goods and services. They coordinate both markets and businesses. Successful entrepreneurs need a rare combination of qualities and experiences. As a result, the surplus of income of a firm transformed into the reward (wage) of the entrepreneur perhaps must be very high[2].

Alfred Marshall (1842-1924) assigns a remarkable role to the entrepreneur, both at the level macro and microeconomic. In his conception, the most important contribution of the entrepreneur is the supply of goods as well as innovation and progress achieved simultaneously. Marshall used an illustration to explain his theory: "The business people who were road opener brought much greater benefits to society than their earnings owns, although millionaires died" [1].

Joseph Schumpeter (1883-1950) considered the entrepreneur as a leader and innovator or "the main engine of the economic system". In Schumpeter's view, the task the entrepreneur is deciding which goal is to be pursued and not to decide how this must be done. He neither assumes the risk nor provides the capital; these tasks are left to the banker (the investor) [5].

Schumpeter sees the entrepreneur as an innovator and a leader, but not as a bearer risk, nor as a capitalist or a manager. The innovator plays the role of engine of growth economics and removes the economy from its static equilibrium, pushing it to the state of a superior balance.

Frank Knight (1885-1972) argues that the entrepreneur also contributes to progress general economy. By pursuing his own goals, he will always improve existing technologies and ways of organization. Entrepreneurs have the responsibility to guarantee the pre-established remuneration for all stakeholders in the firm. They take decisions for which they are responsible and then guarantee fixed payments to production factors use. For this, enough capital (own or borrowed) is needed for 
reimbursement of guaranteed services. The entrepreneur is finally rewarded with the remained profit, as well as with prestige and work satisfaction [5].

\section{The importance of education in entrepreneurial economy}

In entrepreneurial economy, ideas and knowledge being essential for innovation and innovation economic growth, investment in human resources is an important factor in maintaining economic and technological competitiveness. Training Highly Qualified Human Resources, from which feeds into the area of research and development $(\mathrm{R} \& \mathrm{D})$, takes longer, but investment in education or other areas that support the process of lifelong learning brings great value and benefits in economy and society, not only in the short term, but also in the long run long. Building a solid human capacity that is so necessary for the entrepreneurial economy and to which it aspires at European level, is not possible without support through funding appropriate education and research.

In principle, the entire population of a country can be a potential source of human science and technology resources, but the higher - formal education is more consistent, the greater the possibility of employment in R\&D activity [5].

If in most EU Member States the total number of researchers has increased between 2005 and 2015 in Romania was a contrary trend.

The situation in different European countries is uneven, with notable differences between large and small countries, between the north and the south. In northern European countries there is a growing concentration of human resources (i.e. Sweden, Denmark, and Norway). Also in this countries are created organizations specialized in innovation and technologic transfer (GTZ, VINNOVA).

Specialists in the field appreciate that countries with a low potential for researchers do not meet the minimum requirements of the economy based on entrepreneurial knowledge.

Recent developments in Sweden and Finland, which have stimulated an increase in the number of researchers at an already high level, is a good example for Romania, where it was found permanent diminishing of the number of researchers over the last decade.

In the experts' opinion, gaps are difficult to be recovered in the public sector, but especially in the private one [6]. Data shows that in European private firms they are only used half of the researchers compared to the US and Japan, where around $80 \%$ of researchers work in the private sector. This phenomenon is even more worrying than that notes that in European countries the evolution of the number of researchers is contrary to graduates with a qualification appropriate to the $R \& D$ requirements.

In the future, the economy based on entrepreneurial knowledge will stimulate even more increasing the need for people with a high technical and scientific qualification.

Education is entrepreneurship, and the teacher has the role of entrepreneur [5]. That every entrepreneur and teacher must take risks, they must not avoid them. At the moment these risks relate to the transition from a classical higher education system to a system of modern higher education.

In this passage, there are some distinct elements such as:

- in the classical form, students learn from the teacher, and in the modern version, they have to learn from many people in different fields (scientists, psychologists, engineers);

- until now the student has a passive role, in modern education it involves him into participate actively in the exchange of ideas;

- in the classical form, it takes the learning in the organization, it certainly must be replaced by the modern form of discovery learning;

- it is not to be neglected that the classical form promotes education by reaching the target, on when the modern form will promote education to reach the targets.

All this can be possible if Romanian universities will accept to implement as universities in the USA, Germany, Austria, New Zealand entrepreneurship. Unlike the Romanian space where there are often confusing terminologies, in Germany it is a clear distinction between the entrepreneur / entrepreneurial business and the investor [3]. 
The Entrepreneur / Entrepreneurial in Business is the one who comes up with the Idea, and the Investor comes with the Money. They can be the same person ("a cumulus of functions"), but the most common is the one in which are distinct individuals. The investor must believe in Idea, and the Entrepreneur /Entrepreneurial in Business must also come with a minimum amount, or guarantee with his possessions, to take part in taking the risk.

In order to achieve economic growth and the standard of living, Europe needs to stimulate innovation and entrepreneurship. Thus, on the one hand, the gap to competitors will become stronger, and on the other hand, even innovators and entrepreneurs will migrate to more favourable economic space, easy in a globalized world.

The phenomenon of aging of the population occupied in research, which is becoming more and more manifest accentuated in the developed European countries, has already begun to have a negative impact on this field. Young graduates and young researchers are looking for more careers perspective, activity and salary scales. The loss of some younger quotas, which have a greater capacity to adapt to the demands of the knowledge and renewal society continuous knowledge and professional qualification, will accentuate the phenomenon of aging of the population employed in science and technology. This trend is a serious problem at European level, affecting the dynamics of the new knowledge-based economy.

Although, according to surveys, scientists enjoy a good reputation, lack of the attractiveness of this area is, in the case of students, the major obstacle to the way the option for scientific activity.

If European countries have traditionally invested in all forms of education, it has been found that investment in tertiary education does not correlate directly with the number of graduates opting for the profession of researcher.

Some countries have successfully experienced strategies to attract and maintain R\&D of a significant parts of the highly educated population, while in others, attractiveness for other professions or unemployment are factors with a strong influence on degree of occupation in science and technology.

Unemployment data highlights some subtle use of human resources potential for Science and Technology, S\&T. There are about two million unemployed people in the EU countries with or adequate experience for S\&T posts. Amongst the young researchers in Central and Eastern European countries there is a tendency for permanent residence in developed European countries or in the US, Canada, Japan, which have become an important attraction for both researchers from developed countries as well as from other parts of the world.

An important aspect of increasing the number of researchers capturing attention of experts at European level is to stimulate women' participation in R\&D activity through attracting them in universities and then in R\&D.

A human society based on entrepreneurial knowledge must have in its essence the concept of an educated person. The educated person is essential now! It must be able to influence the present, not to mention about modelling future. Knowledge is not cheap. All developed countries allocate about 1/5 of GDP production and dissemination of knowledge. Formal schooling, schooling young people before they get into work - takes about 1/10 of GDP. Organizations are spending another 5 percent of GDP on continuing training for the new employees, or even more. Also 3 to 5 percent in GDP are spent on research development, to produce new knowledge.

Knowledge formation is the largest investment in each developed country. Fifty years ago, people doing work based on knowledge and work in services accounted for less than one third of the workforce. Today, these people constitute three quarters if not four fifths of the labour force of the countries and their proportion is still in increase. One-third of the capital investment in developed countries was spent on equipment for the treatment of data and information: computers, faxes, e mail, television with closed circuit. However, the number of people who work as civil servants, i.e. the number those to whom most of this equipment is destined has increased much faster than total production or GDP. 


\section{Importance of productivity}

The lowest level of productivity is recorded in jobs at state companies. Over the state is the largest patron of services. In the United States, for example, 1/5 of the entire workforce is employed by federal, state and local governments, predominantly in routine office work. In the UK, the proportion is close to $1 / 3$. In all developed countries, government employees represent a similar percentage of total labour force.

If we cannot learn how to increase the productivity of knowledge workers and services, developed countries will have an economic stagnation and severe social tensions. People can only be paid in relation to their productivity. Their productivity creates the common fund of values from which wages are then paid. If productivity does not climb, the more it decreases, the higher real incomes cannot be paid.

Knowledge workers, over time, have to bear a reduction in income if their productivity does not increase. Many service providers submit a job they claim some skill and relatively little education. If an economy, in which productivity service providers is low, trying to pay them wages well over which brings their productivity, inflation is beginning to erode real income for everyone. And no after a long time, inflation will then create serious social tensions. If the service providers would be paid, however, according to their productivity, the distance between their income and that of their "Privileged," i.e. knowledge workers, will gradually increase - creating tensions again severe social issues.

Much of the work in the service does not differ much from the work in product or distribute goods. This includes some features such as data processing, billing, answering customer inquiries, handling insurance claims, issuing driving books for motorists - in fact, nearly two-thirds of the work done in government offices and almost a third or more of all civil servant work in services, in enterprises, universities, hospitals and others. This is the fact "production work", which differs from the work done in a factory only in that is done in an office. But even this work must be "restructured" before become productive. It needs to be studied and restructured to make an optimal contribution and to achieve its objectives.

Working on productivity in the fabrication and movement of things, the task is a data base and determined. When Frederick W. Taylor began to study the load of sand with the shovel, he could take it for granted that the sand should be taken with the shovel. Much of it the work consisting in producing or distributing goods, the task is actually "proportionate machine ": the individual worker serves the machine.

In work based on knowledge and practically in any service work, the machine serves worker. The task is not given: it must be determined, and the question "What are the expected results of this work?" is almost never raised in any traditional work or scientific management study. But it's the key issue to make them productive knowledge workers and service providers. And it's a problem that demands risky decisions. Usually there is no correct answer; there are only choices and the results must be clearly specified if we want to reach productivity.

Entrepreneurial theories have existed for many years. They have contributed to the development and the formation of entrepreneurship as a science. Among the classical thinkers who have formulated the theories.

\section{Conclusions}

Successful entrepreneurs have the ability to see and "sweeten the details" and the also conceptualize. They are dissatisfied with the status quo and are anxious initiators.

Modern research has considerably refined the way self-confidence approaches. There exists widespread agreement between researchers and practitioners, alike, that effective entrepreneurs are looking for actively take the initiative. They are willing to put themselves in situations where they are personal responsible for the success or failure of the operation. They like to have an initiative to solve a problem or fill the gap where there is no leadership. They also like the situations where the personal 
impact on problems can be measured. This is a natural action which oriented an entrepreneur. Successful entrepreneurs are adaptive and resilient. They have an unsteady desire to know how well they do. Realize that to know how much well do and how to improve their performance, they need to look and do use feedback. Searching for and using feedback is also the key to habit learn from mistakes, and respond to unexpected events. For the same reasons, these entrepreneurs are often described as excellent listeners and learners quickly. Entrepreneurs not afraid of failure; on the contrary, they are more focused on success. People who fear failure will neutralize any possible motivation to achieve. They will engage in an easy task, where the chance of failure is very low, or, in a difficult situation where they cannot be found if they fail. Learning through the iterative trial-error process is essential for the goal of becoming a successful entrepreneur, although it brings serious obstacles and disappointments, all of which are an integral part of the learning process.

\section{References}

[1] Andres S 2007 Cultură antreprenorială, Editura Eftimie Murgu, Reşiţa

[2] Drucker P 1993 Innovation and entrepreneurial system, Editura Enciclopedică, Bucureşti

[3] Săvescu D 2015 Modalităţi de creştere economică prin inovare şi transfer tehnologic. Teză de abilitare, Universitatea Transilvania Braşov

[4] Săvescu D 2016, Proprietate intelectuală,Editura Risoprint Cluj Napoca

[5] Schumpeter J 1996 Capitalism, socialism and democracy, London: Routledge

[6] UNESCO, Unesco Education Strategy 2014-2020, disponibil online la http://unesdoc.unesco.org/images/0023/002312/231288e.pdf 